\title{
Evaluation of Early and Mid-term Results of TEVAR Procedures with Various Etiology.
}

\author{
Dilşad Amanvermez Şenarslan ${ }^{1}$, Funda Yıldırım ${ }^{1}$, Ömer Tetik ${ }^{1}$ \\ ${ }^{1}$ Manisa Celal Bayar Üniversitesi, Tıp Fakültesi Kalp Damar Cerrahisi AD, Manisa, Türkiye \\ email: damanvermez@yahoo.com, fundanizamoglu@yahoo.com,omer.tetik@cbu.edu.tr \\ Orcid: 0000-0002-3316-6707 \\ Orcid:0000-0002-1577-0281 \\ Orcid:0000-0003-4471-2686 \\ *Sorumlu Yazar / Corresponding Author: Sorumlu Yazar: Dilşad Amanvermez Şenarslan
}

\author{
Gönderim Tarihi / Received: 01.11.2019 \\ Kabul Tarihi / Accepted: 29.11.2019 \\ DOI: $10.34087 /$ cbusbed.641171
}

\begin{abstract}
Amaç: Torasik endovasküler aort anevrizması tamiri (TEVAR), günümüzde dejeneratif anevrizmalar, sakküler anevrizmalar ve akut torasik aortik sendromların tedavisinde öncelikli tercih edilmektedir. Bu çalışmanın amacı son 3 yılda kliniğimizde uygulanan TEVAR girişimlerinin erken ve orta dönem sonuçlarını değerlendirmektir.

Gereç ve Yöntem: Otuz hastaya (25 erkek, 5 kadın) Ocak 2015-Aralık 2018 arasında TEVAR işlemi uygulandı. Tüm hastalarda Valiant TM Torasik Stent Greft Sistemi (Medtronic $®)$ kullanıldı.

Bulgular: Hastaların yaş ortalaması 60,4 \pm 18 idi. Hastaların \%53,3'ünde dejeneratif anevrizma, \%36,7'sinde akut aortik sendrom, \%10'unda aort koarktasyonu ve eşlik eden poststenotik anevrizma mevcuttu. Hastaların \%63,3'ü semptomatikti ve sırt veya gögüs ağrısı vardı. İşlemlerin teknik başarısı \%100 idi. Yoğun bakım ünitesinde ortalama kalış süresi $1 \pm 2$ gün, hastanede kalış süresi ortalama 3,2 \pm 2 gündü. Hastane mortalitesi olmadı ve ilk 30 günlük dönemde bir hasta tip 2 diseksiyon nedeniyle öldü. İki hastada tip II endoleak görüldü ve endoleak'ler kendiliğinden düzeldiği için ikincil bir müdahaleye ihtiyacımız olmadı. Subklaviyan arterin 3 hastada kapatılması gerekti. Bu hastalarda inme veya sol üst ekstremitede iskemisi gelişmedi. Yeterli hidrasyona rağmen, postoperatif erken dönemde 2 hastanın kreatinin düzeylerinde artış vardı ve izlemde normal değerlere geriledi. Ortalama takip süresi 6 \pm 9 aydı ve uzun vadede 2 mortalite vardı. Bir hasta akciğer kanserinden öldü, ikincisi ise anevrizmal hastalıktan bağımsız olarak mezenterik iskemi nedeniyle öldü.

Sonuç: TEVAR, torasik aort anevrizmaları veya akut aortik sendromların tedavisinde, anatomik olarak uygun hastalarda ilk tedavi seçeneğidir. TEVAR, düşük morbidite ve mortalite oranlarıyla, güvenle uygulanabilir.

Anahtar Kelimeler: Aort anevrizması, disekan anevrizma, endovasküler tedavi
\end{abstract}

Abstract
Objective: Endovascular aneurysm repair in thoracic aorta (TEVAR) is now preferred primarily for the treatment of
degenerative aneurysms, saccular aneurysms and acute thoracic aortic syndromes. The aim of this study was to
evaluate the early and mid-term results of TEVAR procedures that performed in our clinic in the last 3 years.
Materials and Method: Thirty patients ( 25 males, 5 females) underwent TEVAR procedure between January 2015
and December 2018. Valiant TM Thoracic Stent Graft System (Medtronic $($ ) was used in all patients.
Results: The mean age of the patients was $60.4 \pm 18$. Of the patients, $53.3 \%$ had degenerative aneurysm origin,
$36.7 \%$ had acute thoracic aortic syndromes and $10 \%$ had aortic coarctation and concomitant post-stenotic aneurysm.
$63.3 \%$ of the patients were symptomatic and had back or chest pain. Technical success of the procedures was $100 \%$.
The mean duration of stay in the intensive care unit was $1 \pm 2$ days and the mean hospital stay was $3.2 \pm 2$ days.
There was no in-hospital mortality and one patient died of type 2 dissection in the first 30 -day period. Two, type II
endoleak was seen in two patients and we did not need a secondary intervention as the endoleaks resolved
spontaneously. The subclavian artery was required to be closed in 3 patients. We did not observed stroke in those
patients and no ischemia developed in the left upper extremity. Despite adequate hydration, in the early
postoperative period, 2 patients had elevated creatinine levels and regressed to the normal values in the follow-up.


The mean follow-up period was $6 \pm 9$ months and there were 2 mortality in the long term. One patient died of lung cancer and the second died of mesenteric ischemia independently from aneurysmal disease.

Conclusion: TEVAR is the first line therapeutic option in anatomically suitable patients for the treatment of aneurysmal disease of thoracic aorta or acute thoracic aortic syndromes. TEVAR can be applied safely with low morbidity and mortality. Nowadays, as sporting amateur or professional participation increases, the importance of sportive performance and the factors affecting this performance increase. The genetic background in sports has a great impact on the strength, endurance, muscle mass, muscle fibers and lung capacity. Sports genetics studies include the whole range of studies in determining the genes affecting athletic performance, clarifying the mechanisms of action and determining their susceptibility to athletic performance. Examples of genes that can be associated with athletic performance include; can list genes such as myostatin, erythropoietin, growth hormone, nitric oxide synthase, vascular endothelial growth factor, angiotensin converting enzyme, angiotensinogen, monocarboxylate carrier 1, insulin-like growth factor-1, peroxisome proliferator active receptor, alpha-actinin-3. The aim of this study is to investigate genes that are effective in sports science and sports performance.

Keywords: Aortic aneurysm, dissecting aneurysm, endovascular procedure

\section{Introduction}

Thoracic endovascular aortic repair (TEVAR) can be a primary strategy for the treatment of a broad spectrum of thoracic aortic diseases like degenerative aneurismal disease, traumatic disorders and thoracic aortic syndromes (aortic dissection, penetrating aortic ulcer (PAU) and intramural hematoma (IMH)). TEVAR is also the preferred therapy for anatomically feasible adult aortic coarctation patients.

Surgical therapy of descending thoracic aorta mandates a thoracotomy, single-lung ventilation, aortic crossclamping and it has a greater risk of cardiovascular events, respiratory failure, organ malperfusion or paraplegia. Operative mortality ranges between $8 \%$ and $20 \%$ for elective cases according to experience of the center and rises to $50 \%$ for emergency operations. Therefore, surgical therapy has a higher mortality and morbidity compared to endovascular procedures $[1,2]$.

The aim of this study was to evaluate the early and midterm results of TEVAR procedures performed in our tertiary healthcare service with various etiologies, in the last three years and compare it to the literature.

\section{Materials and Methods}

Thirty consecutive patient who underwent TEVAR in our clinic between January 2015 and December 2018 were analyzed for the study. After approval of the local ethical committee, the data collected retrospectively from the hospital records. All the interventions were performed by cardiovascular surgeons in a hybrid operating room. Valiant TM Thoracic Stent Graft System with the Captivia delivery system (Medtronic $\AA$ ) was used in all patients. The interventions are performed under sedation and local anesthesia. The femoral artery that the delivery system was introduced, exposed surgically by a small incision and a 7 French sheath was inserted in the contralateral femoral artery. Patients came to the hospital for a routine visit in the second week, first and third month after the operation and then, after six months. The control computed tomography angiography (CTA) was obtained at the first month and 6th month after the intervention.
The statistical analysis was performed with the SPSS 22.0 statistical software. Demographic data were analyzed by using descriptive statistical methods and were shown as mean \pm standard deviation and frequency.

\section{Results}

Thirty patients enrolled to the study, 25 of them were male $(83.3 \%)$ and 5 of them were female $(16.6 \%)$. The mean age of the patients was $60.4 \pm 18.0$ years (range 21 85 years). Most of them were symptomatic (63.3\%) and back-pain was the primary symptom. Table 1 demonstrates the general characteristics of the patients. Hypertension and chronic obstructive pulmonary disease (COPD) were most commonly seen co morbidities. Almost half of them were smokers. There were 3 patients $(10 \%)$ who had hereditary history of aneurysmal disease.

Table 1. General characteristics of the patients Characteristics

\begin{tabular}{|c|c|}
\hline Mean age (year-old) & $60.4 \pm 18$ \\
\hline Gender (male/female) (n) & $\begin{array}{llll}25 & (83.3 \%) & / & 5 \\
(16.6 \%) & & \end{array}$ \\
\hline Symptomatic patients (n) & $19(63.3 \%)$ \\
\hline Hypertension (n) & $18(60 \%)$ \\
\hline Diabetes (n) & $2(6.6 \%)$ \\
\hline Hyperlipidemia (n) & $5(16.6 \%)$ \\
\hline
\end{tabular}

Chronic obstructive pulmonary $11(36.6 \%)$

disease (COPD) (n)

\begin{tabular}{|ll|} 
Chronic kidney failure (n) & $2(6.6 \%)$ \\
\hline Smoking & $17(56.6 \%)$ \\
\hline Hereditary history $(n)$ & $3(10 \%)$ \\
\hline
\end{tabular}

CAD: Coronary artery disease, COPD: Chronic obstructive pulmonary disease, $\mathbf{n}$ : patient number 
Most of the patients who underwent TEVAR procedure had degenerative aneurysmal disease (53.3\%). Acute aortic syndromes (AAS) were the secondary reason for endovascular therapy of the descending aorta (36.7\%). There were also 3 patients who treated by TEVAR for adult aortic coarctation. Etiology of the endovascular interventions for the descending aorta are shown in Table 2. Technical success of the procedures was $100 \%$. Type II endoleak was seen in two patients (6.6\%). The endoleaks resolved spontaneously within 2 months and no secondary intervention was required.

Table 2. Etiology of the endovascular interventions for the descending aorta.

\begin{tabular}{|l|l|}
\hline Indications for TEVAR & Patients (n) \\
\hline Degenerative aneurysm & $16(53.3 \%)$ \\
\hline Acute thoracic aortic syndromes & $11(36.7 \%)$ \\
\hline \multicolumn{1}{|c|}{ Traumatic injury } & $6(20 \%)$ \\
\hline \multicolumn{1}{|c|}{ Penetrated aortic ulcer } & $2(6.7 \%)$ \\
\hline $\begin{array}{l}\text { Aortic coarctation and concomitant } \\
\text { poststenotic aneurysm }\end{array}$ & $3(10 \%)$ \\
\hline $\begin{array}{l}\text { Total } \\
\text { TEVAR: Thoracic endovascular } \\
\text { repair, n: number of the patient }\end{array}$ & aneurysm \\
\hline
\end{tabular}

We did not observe any myocardial infarction or an end organ malperfusion like stroke, spinal cord ischemia and paraplegia in the early postoperative period. Two patient's TEVAR coverage was exceeding $20 \mathrm{~cm}$ in length and we used cerebrospinal fluid (CSF) drainage system to reduce the risk of spinal cord injury. We inserted the drainage system before the intervention, and we monitored it for 48-72 hours. Two patients had fever after the stent graft implantation that was thought to be related to post implantation syndrome and the fever controlled by paracetamol administration. The subclavian artery was required to be closed in 3 patients $(10 \%)$ because of the inadequacy of the proximal neck distance. (Figure 1) After the intervention, there was no significant difference in arterial blood pressure between the right and the left extremity and no ischemia was developed in the left arm after the procedure. Also, we did not observed stroke in those patients.

The mean duration of stay in the intensive care unit (ICU) was $1 \pm 2$ days and the mean hospital stay was $3.2 \pm 2$ days. There was no in-hospital mortality. One patient died of type 2 dissection in the first 30-day period. In the early postoperative period (30 days), two patients had elevated creatinine levels $(>2 \mathrm{mg} / \mathrm{dl})$ because of opaque related nephropathy and regressed to the normal values in the follow-up with hydration. We did not observe any major cardiovascular adverse event (MI, stroke), in the first 30-day period.

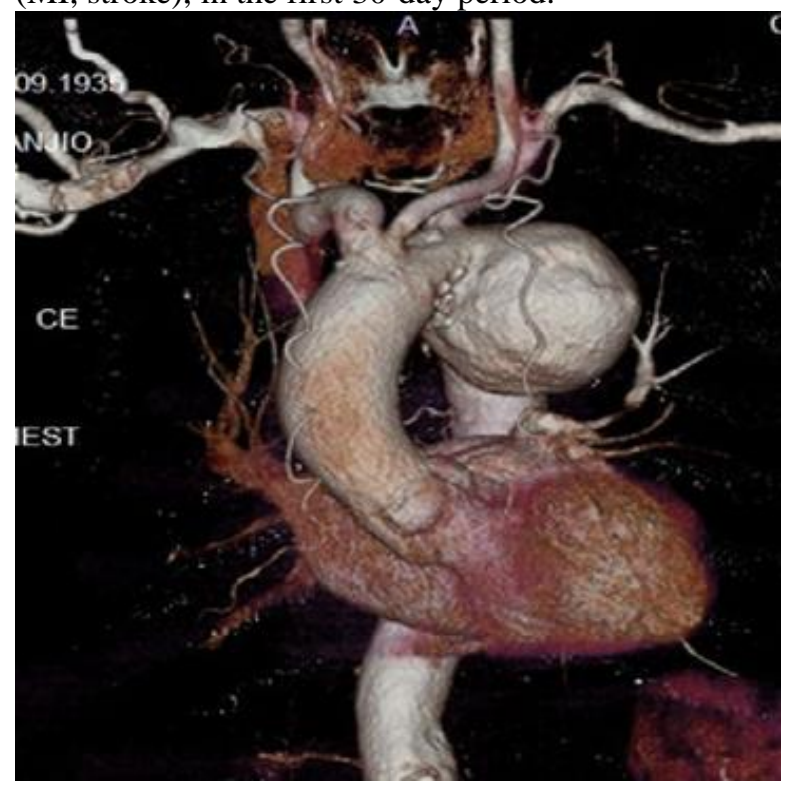

Figure 1. Computed tomography angiography view of a patient with a saccular aneurysm at just below the subclavian artery orifice. The left subclavian artery entry had to be covered with the stent graft because of inadequate proximal landing zone.

We performed TEVAR procedure in 3 patients for adult aortic coarctation who were anatomically suitable for the endovascular intervention. They were diagnosed by cardiology department with severe uncontrolled hypertension and they all had $>20 \mathrm{~mm} \mathrm{Hg}$ aortic gradient at the level of coarctation segment and concomitant post stenotic aneurysms. No complication occurred related to the endovascular intervention in this subgroup of patients too.

The mean follow-up period was $6 \pm 9$ months. There was no endoleak and no need for secondary intervention in the follow-up. The mortality rate was $2(6.6 \%)$ in the long term, independent from the TEVAR procedure. One patient died of lung cancer and the second died of mesenteric ischemia and sepsis. The overall mortality rate was $10 \%$ (3 patients) after the TEVAR procedure.

\section{Discussion}

TEVAR procedures initially designed for the treatment of aneurysmal disease of the aorta which has primarily degenerative origin. Most of the thoracic aorta aneurysms are asymptomatic and encountered incidentally. The incidence seems to be increasing with ageing. The thoracic aneurysms tend to enlarge and may cause a life-threatening condition when the aneurysm is ruptured. The overall incidence rate of TAA is about 10 per 100,000 person-years. The descending aorta is involved in about $30 \%$ to $40 \%$ of these cases. The prognosis of large untreated TAAs is poor, with a 3-year 
survival rate as low as $25 \%$. Intervention is strongly recommended for any symptomatic TAA or any TAA that exceeds twice the diameter of a normal aorta or is 6 $\mathrm{cm}$ or larger [2,3].

Technical success of the TEVAR procure is ranged from \%95-99 [3,4]. High technical success of our study group was related to delicate patient selection and planning of the procedure and achieving optimal environmental conditions in our hybrid operating room. There was no vascular injury because we inserted the delivery system under direct vision and controlled the entry hole of the artery with a purse string suture from a small incision. Perioperative mortality of open surgical repair for thoracic aortic aneurysm ranges from $2.7 \%$ to $8 \%$ and increases up to $29 \%$ in traumatic descending aortic rupture. In a meta-analysis of 17 studies which is comparing elective open repair and TEVAR results, TEVAR group had a lower mortality rate $(5.5 \%$ vs. $16.5 \%$ ) and neurological injury. TEVAR had a reduced ICU and hospital stay. Endovascular stenting had no impact on the major reintervention rate.[5] Our early and mid-term morbidity and mortality rates and postoperative complication rates are low and consistent with the literature [3-8]. We did not need any major reintervention in our study group.

Type B aortic dissection (TBAD) has an incidence between 2.9 and 4.0 per 100,000 person-years [3]. Endovascular treatment is life saving in patients with complicated TBAD; contained rupture and organ malperfusion syndromes. Patients who present with unstable TBAD manifesting renal or mesenteric ischemia have an operative mortality rate of $50 \%$ and $88 \%$, respectively. TEVAR is also recommended for ongoing pain, and resistant hypertension [9]. IRAD study which enrolled over 2000 patients from multicenter reported an in-hospital mortality rate of $32 \%$ for surgically treated patients, $7 \%$ for those managed with endovascular techniques, and $10 \%$ for those managed with medical therapy alone $[9,10]$ Currently, stable patients with TBAD are managed conservatively. However, there is a risk of rupture in the long term because of the expansion of the false lumen. Closing the entry tear with a stent graft, isolates the false lumen from the aortic flow, enhances remodeling, ensures that the true lumen remains patent and improves the outcomes of TBAD in the long term [11]. The INSTEAD trial showed that optimum medical therapy with close surveillance has the similar rates of all cause and aorta related survival rates and adverse events with elective stent graft placement within two years. However, TEVAR with optimal medical therapy group showed a favorable aortic remodeling [11]. INSTEADXL trial showed improved 5-year aorta specific survival and delayed disease progression in TEVAR group [12]. ADSORB trial which was a prospective randomized trial also showed benefits of TEVAR for false lumen thrombosis and diameter of the aorta at 1-year results [13]. A recent study compared uncomplicated acute type
B aortic dissections (UATBAD) with intractable pain or refractory hypertension which are treated with TEVAR or best medical therapy. The study showed that TEVAR was safe but did not offer a better short term outcome than the patients who are taking best medical therapy [14]. In our study group there were 2 patients with complicated acute type $\mathrm{B}$ dissection and one patient with a chronic type $B$ dissection who have unthrombosed false lumen with progressive enlargement of diameter.

According to IRAD study intramural hematoma (IMH) accounts for $5-20 \%$ of the cases who are presenting with acute aortic syndromes. Nearly $10 \%$ of them regress with medical treatment, but $28-47 \%$ of them progress to classical aortic dissection and carry $20-45 \%$ risk of rupture.[10] In this study there was 2 patients with penetrated aortic ulcer, both of them had applied to the hospital with backpain.

In our series, a female patient who had aneurysmal disease and presented with refractory backpain had a retrograde dissection two weeks after her discharge from the hospital. The patient treated by open surgery and died of acute kidney failure in ICU. There is a limited data about retrograde type A aortic dissection (RTAD) that is a potentially lethal complication after TEVAR [15-18]. A recent meta-analysis pooled estimation for incidence of RTAD was $2.5 \%$ and for mortality was $37.1 \%$. Incidence of RTAD is significantly more frequent in patients treated for dissection than those with an aneurysm and when the proximal bare stent was used [16].

Blunt traumatic thoracic aortic injury has a high mortality rate and is the second most common cause of death in trauma patients after intracranial hemorrhage.[19] In the past studies, traumatic thoracic aortic transections which were treated by surgical therapy was associated high mortality (nearly 28\%) and paraplegia $(16 \%)$ rate $[19,20]$. Nowadays, TEVAR is increasingly preferred for the treatment of traumatic thoracic injuries. In a polytrauma patient, early stabilization of the aortic pathology is of the utmost importance. TEVAR may be a rapid and an optimal solution for hemodynamic stabilization of the patient. Thereby, the physicians can avoid further blood loss with thoracotomy incision, cardiopulmonary bypass and heparinization side effects especially in patients with head and abdominal solid organ injuries. Timing of the endovascular intervention, size and configuration of the aortic landing zones, frequent need to cover subclavian artery makes the intervention more complicated. Limited number of meta-analysis and the clinical practice guideline of Society for Vascular Surgery (SVS) which is related to endovascular repair of traumatic aortic injury indicated that the mortality rates was significantly lower in patients who underwent endovascular repair, followed by open repair and then nonoperative management $(9 \%, 19 \%$ and $46 \%$, 
respectively). While the stroke risk was similar among the groups, the risk of spinal cord ischemia and end stage renal disease was higher in surgical therapy group, compared with endovascular repair and non operative management. There was a trend toward increased risk of a secondary procedure in endovascular treatment group compared with open repair group in the long term [19,21]. SVS consensus guideline suggest urgent (within 24 hours) repair for grade II, III and IV injuries because of the risk of rupture or aortic repair immediately after other injuries have been treated but the Eastern Association for the Surgery of Trauma Management guidelines which was published in 2015 recommended delayed repair and maintaining effective blood pressure control [22]. The SVS committee suggested lower dose heparinization than standard TEVAR intervention with a low quality of evidence and a case selective left subclavian artery revascularization (LSA) and doesn't recommend routine CSF drainage. Trauma patients are usually young, and the diameter of the aorta is relatively smaller than degenerative aneurysms. Excessive oversizing may lead endoleak, device infolding, endograft collapse, death from acute aortic occlusion or a rupture. There is no consensus regarding optimal oversizing. Some of the physicians prefer no oversizing while some of them prefer 5\%-10\% oversizing [19,21]. An individual based decision and also recommendations of the device manufacturer is important. In our center we usually choose no oversizing the endograft in trauma patients.

LSA orifice may be closed if there is not adequate proximal landing zone, but a careful follow-up of blood pressure difference and ischemia is needed. Several studies suggest that if the LSA origin is closed in TEVAR procedures, the intervention should be proceeded by prophylactic revascularization to diminish the risk of stroke and upper extremity ischemia [23,24]. Carotid subclavian bypass or subclavian -carotid transposition can be preferred for revascularization of LSA. Coverage of the LSA may lead to a greater risk of posterior cerebral artery territory stroke due to cessation of the left vertebral artery flow. Patterson et al. and Waterford et al. underlined that the revascularization of LSA may lower especially the rate of posterior stroke. The requirement for extensive aortic coverage and a history of previous cerebrovascular disease was predictive for stroke $[25,26]$. Also, a recent metaanalysis including 1161 patients reported similar risk of stroke and mortality between LSA revascularized patients and non-revascularized patient groups who underwent TEVAR with LSA coverage. The researchers emphasized that further randomized clinical trials is needed to elucidate the exact role of LSA revascularization before the routine use of the technique [27]. LSA revascularization before TEVAR, compared with post-TEVAR revascularization, had lower perioperative cardiopulmonary complications. In highrisk patients, endovascular LSA revascularization may be recommended over open surgery [28]. In our study the LSA was closed in 3 patients without revascularization, none of them developed cerebral or left upper extremity ischemia in the long term.

Coarctation of the aorta $(\mathrm{CoA})$ is a common congenital heart defect. TEVAR procedures can be an effective and safe option for the treatment of adult aortic coarctation patients who are anatomically suitable. Three patients with $\mathrm{CoA}$ in our study group were diagnosed with severe uncontrolled hypertension. They all had $>20 \mathrm{~mm}$ $\mathrm{Hg}$ aortic gradient at the level of coarctation segment and concomitant post stenotic aneurysms. A satisfactory aortic gradient fall was ensured with endovascular therapy without any complication in all the patients.

The major limitation of the study is small number of the groups and the follow-up time is relatively shorter than those of the large volumed centers.

\section{Conclusions}

TEVAR is the first line therapeutic option for the treatment of aneurysmal disease of descending aorta or acute thoracic aortic syndromes. In anatomically suitable patients to TEVAR, good results can be achieved with careful preprocedural planning. TEVAR can be applied safely for various aortic pathology with low morbidity and mortality. Surgical therapy is still a complementary treatment modality for the complex aortic pathologies but, it seems that the indications for endovascular therapy will be broadened in the future.

\section{References:}

1. Roselli EE, Thoracic endovascular aortic repair versus open surgery for type-B chronic dissection, The Journal of Thoracic and Cardiovascular Surgery, 2015, 149(2), S163167.

2. Medical Advisory Secretariat, Endovascular repair of descending thoracic aortic aneurysm: an evidence-based analysis, Ontario Health Technology Assessment Series, 2005, 5(18): 1-59.

3. Riambau V, Böckler D, Brunkwall J, Cao P, Chiesa R, Coppi G, et al, Editor's Choice- Management of Descending Thoracic Aorta Diseases: Clinical Practice Guidelines of the European Society for Vascular Surgery (ESVS), European Journal of Vascular and Endovascular Surgery, 2017, 53(1), 4-52.

4. Eggebrecht H, Nienaber CA, Neuhäuser M, Baumgart D, Kische S, Schmermund A, et al, Endovascular stent-graft placement in aortic dissection: a meta-analysis, European Heart Journal, 2006, 27(4), 489-98.

5. Walsh SR, Tang TY, Sadat U, Naik J, Gaunt ME, Boyle JR, et al, Endovascular stenting versus open surgery for thoracic aortic disease: systematic review and meta-analysis of perioperative results, Journal of Vascular Surgery, 2008, 47(5), 1094-8.

6. Li QG, Yu WD, Ma WG, Large clinical registries for acute aortic dissection: interpretation and comparison of latest results, Zhonghua Wai Ke Za Zhi [Chinese Journal of Surgery], 2019, 57(5), 326-30.

7. Erben Y, Oderich GS, Verhagen HJM, Witsenburg M, van den Hoven AT, Debus ES, et al, Multicenter experience with endovascular treatment of aortic coarctation in adults, Journal of Vascular Surgery, 2019, 69(3), 671-679.e1.

8. Hagan PG, Nienaber CA, Isselbacher EM, Bruckman D, Karavite DJ, Russman PL, et al, The International Registry of Acute Aortic Dissection (IRAD): new insights into an old disease, JAMA, 2000, 283(7), 897-903. 
9. Nienaber $\mathrm{CA}$, Kische $\mathrm{S}$, Ince $\mathrm{H}$, Fattori $\mathrm{R}$, Thoracic endovascular aneurysm repair for complicated type B aortic dissection, Journal of Vascular Surgery, 2011, 54(5), 152933.

10. Tsai TT, Trimarchi S, Nienaber CA, Acute aortic dissection: perspectives from the International Registry of Acute Aortic Dissection (IRAD), European Journal of Vascular and Endovascular Surgery, 2009, 37(2): 149-59.

11. Nienaber CA. Influence and critique of the INSTEAD Trial (TEVAR versus medical treatment for uncomplicated type B aortic dissection), Seminars in Vascular Surgery, 2011, 24(3), 167-71.

12. Nienaber $\mathrm{CA}$, Kische $\mathrm{S}$, Rousseau $\mathrm{H}$, Eggebrecht $\mathrm{H}$, Rehders TC, Kundt G, et al, Endovascular repair of type B aortic dissection: long-term results of the randomized investigation of stent grafts in aortic dissection trial, Circulation. Cardiovascular Interventions, 2013, 6(4), 40716.

13. Brunkwall J, Kasprzak P, Verhoeven E, Heijmen R, Taylor P, ADSORB Trialists, et al, Endovascular repair of acute uncomplicated aortic type B dissection promotes aortic remodelling: 1 year results of the ADSORB trial, European Journal of Vascular and Endovascular Surgery, 2014, 48(3), 285-91.

14. Laquian L, Scali ST, Beaver TM, Kubilis P, Beck AW, Giles K, et al, Outcomes of Thoracic Endovascular Aortic Repair for Acute Type B Dissection in Patients With Intractable Pain or Refractory Hypertension, Journal of Endovascular Therapy, 2018, 25(2), 220-9.

15. Canaud L, Ozdemir BA, Patterson BO, Holt PJE, Loftus IM, Thompson MM, Retrograde aortic dissection after thoracic endovascular aortic repair, Annals of Surgery, 2014, 260(2), 389-95.

16. Chen Y, Zhang S, Liu L, Lu Q, Zhang T, Jing Z, Retrograde Type A Aortic Dissection After Thoracic Endovascular Aortic Repair: A Systematic Review and Meta-Analysis, Journal of the American Heart Association, 2017, 6(9)

17. An Z, Song Z, Tang H, Han L, Xu Z, Retrograde Type A Dissection after Thoracic Endovascular Aortic Repair: Surgical Strategy and Literature Review, Heart, Lung \& Circulation, 2018, 27(5), 629-34

18. Ma T, Dong ZH, Fu WG, Guo DQ, Xu X, Chen B, et al, Incidence and risk factors for retrograde type A dissection and stent graft-induced new entry after thoracic endovascular aortic repair, Journal of Vascular Surgery, 2018, 67(4), 1026-1033.e2.

19. Lee WA, Matsumura JS, Mitchell RS, Farber MA, Greenberg RK, Azizzadeh A, et al, Endovascular repair of traumatic thoracic aortic injury: clinical practice guidelines of the Society for Vascular Surgery, Journal of Vascular Surgery, 2011, 53(1), 187-92.

20. Cowley RA, Turney SZ, Hankins JR, Rodriguez A, Attar S, Shankar BS, Rupture of thoracic aorta caused by blunt trauma. A fifteen-year experience, The Journal of Thoracic and Cardiovascular Surgery, 1990, 100(5), 652-60; discussion 660-661.

21. Murad MH, Rizvi AZ, Malgor R, Carey J, Alkatib AA, Erwin PJ, et al, Comparative effectiveness of the treatments for thoracic aortic transection, Journal of Vascular Surgery, 2011, 53(1), 193-199.e1-21.

22. Fox N, Schwartz D, Salazar JH, Haut ER, Dahm P, Black JH, et al, Evaluation and management of blunt traumatic aortic injury: a practice management guideline from the Eastern Association for the Surgery of Trauma, The Journal of Trauma and Acute Care Surgery, 2015, 78(1), 136-46.
23. Chung J, Kasirajan K, Veeraswamy RK, Dodson TF, Salam AA, Chaikof EL, et al, Left subclavian artery coverage during thoracic endovascular aortic repair and risk of perioperative stroke or death, Journal of Vascular Surgery, 2011, 54(4), 979-84.

24. Zamor KC, Eskandari MK, Rodriguez HE, Ho KJ, Morasch MD, Hoel AW, Outcomes of Thoracic Endovascular Aortic Repair and Subclavian Revascularization Techniques, Journal of the American College of Surgeons, 2015, 221(1), 93-100.

25. Waterford SD, Chou D, Bombien R, Uzun I, Shah A Khoynezhad A, Left Subclavian Arterial Coverage and Stroke During Thoracic Aortic Endografting: A Systematic Review, The Annals of Thoracic Surgery, 2016, 101(1), 381-9.

26. Patterson BO, Holt PJ, Nienaber C, Fairman RM, Heijmen $\mathrm{RH}$, Thompson MM, Management of the left subclavian artery and neurologic complications after thoracic endovascular aortic repair, Journal of Vascular Surgery, 2014, 60(6), 14911497.e1.

27. Hajibandeh S, Hajibandeh S, Antoniou SA, Torella F, Antoniou GA, Meta-analysis of Left Subclavian Artery Coverage With and Without Revascularization in Thoracic Endovascular Aortic Repair, Journal of Endovascular Therapy, 2016, 23(4), 634-41.

28. Delafontaine J-L, Hu B, Tan T-W, Tang GL, Starnes BW, Virk C, et al, Outcome Comparison of TEVAR with and without Left Subclavian Artery Revascularization from Analysis of Nationwide Inpatient Sample Database, Annals of Vascular Surgery, 2019 (Epub, doi: 10.1016/j.avsg.2019.01.005.)

http://edergi.cbu.edu.tr/ojs/index.php/cbusbed isimli yazarın CBU-SBED bașlıklı eseri bu Creative Commons AlıntıGayriticari4.0 Uluslararası Lisansı ile lisanslanmıştır. 